\title{
ANALISIS SWOT DALAM PENGEMBANGAN BISNIS (Studi pada Sentra Jenang di Desa Wisata Kaliputu Kudus)
}

\author{
Istiqomah dan Irsad Andriyanto \\ Dosen Syariah Dan Ekonomi Islam \\ irsad.smg@gmail.com
}

\begin{abstract}
The rapid business competition encourages every company to have a sharp strategy in order to excel in competing with its competitors or at least able to stay afloat to run its business. This study aims to analyze opportunities and business development at Sentra Jenang in Kaliputu Kudus Tourism Village. Respondents of this research are entrepreneurs who are located in Sentra Jenang Tourism Village kaliputu Kudus. The research data obtained by observation and interview is analyzed descriptively by using SWOT strategy matrix to analyze the strategy specified by the respondents. The results of this study indicate that there are some problems faced by some small entrepreneurs that are difficult to develop due to not have a place to market their products, the quality of human resources that are poorly trained to inhibit the production process, the company does not have good financial management so that difficulty for the management of funds, with increasingly fierce competition. The competition that arises more on jenang products from outside Kaliputu and the inclusion of substitution products that other snacks are more modern and follow the development of the era. From the threats that exist then every MSME or jenang industry in the tourist village of Kaliputu Kudus should make innovations of new variants in order to compete in the market and not inferior to other products.
\end{abstract}

Keywords: competition, innovations, market

\section{A. Pendahuluan}

Salah satu persoalan dalam membangun ekonomi Indonesia adalah kurangnya jumlah wirausahawan. Jumlah wirausahawan yang ideal dalam suatu negara mendekati 10\%, sedangkan di Indonesia masih di bawah $2 \%$. Oleh karena itu untuk 
mempertahankan laju pertumbuhan ekonomi diperlukan partisipasi dari masyarakat untuk menjadi wirausahawan baru. Sejarah menunjukkan bahwa Usaha Mikro Kecil Menengah (UMKM) kurang mendapatkan perhatian di Indonesia sebelum krisis pecah pada tahun 1997 (Hamali, 2016: hal.112).

UMKM mempunyai peran yang strategis dalam pembangunan ekonomi nasional. Selain berperan dalam pertumbuhan ekonomi dengan penyerapan tenaga kerja juga berperan dalam pendistribusian hasil-hasil Industri. Dalam masa krisis ekonomi yang beberapa tahun lalu, banyak usaha berskala besar mengalami kemacetan bahkan berhenti aktifitasnya. Sektor UMKM terbukti lebih tangguh dalam menghadapi masa tersebut. Namun demikian, hal ini tetap tidak menutup kemungkinan bahwa masih banyak terdapat kelemahan yang melekat pada sektor UMKM seperti halnya dalam akses informasi. Dengan keterbatasan ini, UMKM yang sebenarnya memiiki potensi pangsa pasar yang cukup besar di dunia Internasional, pada kenyataannya masih belum banyak diketahui konsumen sehingga minat Masyarakat terhadap UMKM masih rendah.

Suatu bisnis berjalan jika ada peluang pasarnya. Peluang pasar yang teridentifikasi dan ditangkap oleh seorang wirausahawan merupakan responnya untuk memecahkan masalah yang ada di dalam masyarakat. Seseorang wirausahawan akan mengeksplorasi peluang tersebut untuk kemudian menciptakan suatu produk atau jasa dalam rangka memenuhi kebutuhan lingkungan masyarakat.

Melalui produk dan jasa tersebut diharapkan masalah yang dihadapi masyarakat dapat terselesaikan secara tuntas. Bagi seorang pengusaha suatu usaha dimulai karena adanya suatu peluang (opportunity) bisnis dan ketertarikan pada keuntungan yang diharapkan dari usaha tersebut. Mewujudkan suatu peluang menjadi suatu kenyataan adalah suatu proses yang memerlukan waktu yang relatif cukup lama. Waktu diperlukan untuk mengatur prasyarat, seperti menjajaki layak tidaknya suatu usaha tersebut (Anoraga, 2011: hal. 5-7).

Peluang bisnis adalah kesempatan atau waktu yang tepat yang seharusnya diambil oleh seorang wirausahawan untuk 
mendapat keuntungan. Keberhasilan dalam menangkap peluang usaha akan membuka keberhasilan lainnya yang ditentukaan oleh faktor teknologi, komunikasi dan informasi. Seseorang wirausahawan harus cerdik meangkap dan memanfaatkan peluang kemudian mengambil keputusan yang tepat dengan memanfaatkan sumber daya, baik yang ada dalam kepemilikannya maupun yang ada dilingkungan eksternal secara kreatif.

Membaca peluang pasar merupakan komponen kunci agar analisis peluang bisnis bisa dikembangan seakurat mungkin. Dengan membaca peluang pasar secara cermat, maka dapat diketahui apakah produk yang diciptakan mempunyai peluang untuk diserap pasar atau tidak. Seandainya produk terserap pasar maka harus teridentifikasi apa yang menjadi penyebabnya dan apa yang sebenarnya dibutuhkan oleh konsumen (Pramudiana dkk, 2016: hal.11-12).

Peluang bisnis yang sudah terbuka luas memerlukan adanya pengembangan. Dalam arti luas pengembangan adalah upaya pendidikan baik formal maupun non formal yang dilaksanakan secara sadar, berencana, terarah, teratur, dan bertanggung jawab dalam rangka memperkenalkan, menumbuhkan, membimbing, dan mengembangkan suatu dasar kepribadian yang seimbang, utuh dan selaras, pengetahuan dan keterampilan sesuai dengan bakat, keinginan serta kemampuannya, meningkatkan dan mengembangkan dirinya, sesama, maupun lingkungannyake arah tercapainya martabat, mutu dan kemampuan manusiawi yang optimal dan pribadi yang mandiri. Pengembangan adalah prihal berkembang dan selanjutnya, kata berkembang juga berarti mekar terbuka atau membentang, menjadi besar, luas dan banyak, serta menjadi bertambah sempurna dalam hal kepribadian pikiran, pengetahuan dan sebagainya (KBBI, 1991: hal.205).

Saat wirausahawan menciptakan suatu ide bisnis, mereka juga harus memperhatikan bagaimana menerapkan fungsi-fungsi bisnis yang baru saja digambarkan, untuk membuat bisnis yang berhasil. Mereka harus menciptakan rencana bisnis, yaitu suatu diskripsi dari bisnis, jenis pelanggan yang ingin ditarik, kondisi persaingan, dan fasilitas yang diperlakukan untuk produksi. 
Dewasa ini Perusahaan yang berskala UMKM sedang gencar-gencarnya mendapat perhatian dari pemerintah baik tingkat Kabupaten/Kota, Provinsi maupun tingkat Nasional. Karena perkembangan UMKM dinilai pemerintah membantu meningkatkan Pendapatan Nasional serta dapat mengurangi jumlah pengangguran.

Desa Kaliputu merupakan salah satu desa yang ditetapkan oleh Pemerintah Kabupaten Kudus sebagai Desa Wisata sejak ditetapkan pada tahun 2013 yang bergerak dalam sentra jenang. Hal ini mengingat banyaknya masyarakat sekitar yang membangun usaha yang bergerak dalam industri jenang. Perusahaan Jenang di Desa Wisata Kaliputu berjumlah lebih dari 30 UMKM, di antaranya adalah Jenang Karomah, Jenang Risqina, dan Jenang Menara. Ketiga jenang tersebut adalah hasil karya tangan masyarakat Desa Kaliputu.

Tujuan pemerintah menetapkan Desa Kaliputu sebagai desa wisata adalah untuk membuka peluang dan pengembangan bisnis UMKM khususnya usaha jenang di desa tersebut. Jenang adalah makanan khas Kudus yang memiliki cita rasa unik, yang terbuat dari bahan dasar tepung dan gula. Jenang sering dijumpai menjadi jajanan khas saat lebaran dan juga menjadi oleh-oleh bagi wisatawan regional yang datang ke kota Kudus.

\section{B. Kajian Pustaka}

\section{Pengembangan Bisnis}

Pengembangan dalam arti yang sangat sederhana adalah suatu proses, cara pembuatan. Sedangkan dalam arti luas adalah upaya pendidikan baik formal maupun non formal yang dilaksanakan secara sadar, berencana, terarah, teratur, dan bertanggung jawab dalam rangka memperkenalkan, menumbuhkan, membimbing, dan mengembangkan suatu dasar kepribadian yang seimbang, utuh dan selaras, pengetahuan dan keterampilan sesuai dengan bakat, keinginan serta kemampuan-kemampuannya, meningkatkan dan mengembangkan dirinya, sesama, maupun lingkungannya ke arah tercapainya martabat, mutu dan kemampuan manusiawi yang optimal dan pribadi yang mandiri. 
Pengembangan adalah prihal berkembang dan selanjutnya, kata berkembang juga berarti mekar terbuka atau membentang, menjadi besar, luas dan banyak, serta menjadi bertambah sempurna dalam hal kepribadian pikiran, pengetahuan dan sebagainya (KBBI, 1991). Saat wirausahawan menciptakan suatu ide bisnis, mereka juga harus memperhatikan bagaimana menerapkan fungsi-fungsi bisnis yang baru saja digambarkan, untuk membuat bisnis yang berhasil. Mereka harus menciptakan rencana bisnis, yaitu suatu diskripsi dari bisnis, jenis pelanggan yang ingin ditarik, kondisi persaingan, dan fasilitas yang diperlakukan untuk produksi.

\section{Pengembangan Perencanaan Bisnis}

Mengembangkan bisnis juga harus melihat rencana-rencana bisnis, ada beberapa lingkungan yang mengelilingi bisnis yaitu lingkungan ekonomi, lingkungan industri, dan lingkungan global.

\section{a. Lingkungan Ekonomi}

Lingkungan ekonomi diperkirakan untuk menentukan bagaimana permintaan untuk produk mungkin berubah dalam memberikan reaksi kepada kondisi ekonomi yang akan datang. Permintaan suatu produk dapat menjadi sangat sensitif tergantung kekuatan ekonomi. Namun demikian, kelayakan bisnis baru mungkin dipengaruhi lingkungan ekonomi.

\section{b. Lingkungan Industri}

Lingkungan industri juga perlu diperkirakan untuk menentukan tingkat pesaing, jika pasar untuk produksi spesifik hanya dilayani oleh sedikit dan beberapa perusahaan, maka perusahaan baru mungkin dapat menangkap porsi yang signifikan dari pasar.Seseorang wirausaha juga harus bertanya apakah produk serupa dapat diproduksi dan dijual dengan harga lebih rendah, dengan tetap memberikan keuntungan yang wajar.

Pertanyaan yang berkaitan adalah apakah bisnis baru akan dapat memproduksi suatu produk kualitas tinggi daripada produk pesaing. Ide bisnis baru akan cenderung berhasil apabila mempunyai keunggulan harga atau kualitas daripada pesaingnya. 


\section{c. Lingkungan Global}

Lingkungan global perlu diperkirakan untuk menentukan bagaimana permintaan produk mungkin berubah dalam reaksi kepada kondisi global yang akan datang. Permintaan global suatu produk bisa sangat sensitif mengubah ekonomi luar negri, jumlah pesaing asing, kurs mata uang, dan regulasi perdagangan internasional.

Salah satu pengembangan bisnis yaitu yang bergerak dalam usaha kecil dan menengah, usaha kecil dan menengah merupakan salah satu kekuatan pendorong terdepan dalam pembangunan ekonomi. Gerak sektor UKM sangat vital untuk menciptakan pertumbuhan dan lapangan pekerjaan. UKM cukup fleksibel dan dapat dengan mudah beradaptasi dengan pasang surut dan arah permintaan pasar. UKM juga menciptakan plapangan pekerjaan yang lebih cepat dibandingkan sektor usaha lainnya, dan UKM juga memberikan konstribusi penting dalam ekspor dan perdagangan.

Kuncoro (dalam Pramiyanti, 2008) mengemukakan bahwa UKM harus diberi kesempatan untuk berkembang dengan berbagai cara, sebagai berikut :

\section{a. Mengurangi regulasi yang membebani UKM.}

Era desentralisasi membuat lebih dari 400 pemerintah daerah mengeluarkan sejumlah aturan usaha yang menghambat pertumbuhan dan gerak usaha. Sejumlah regulasi telah mengurangi daya saing UKM karena harus menghabiskan sejumlah uang dan waktu untuk dapat memenuhi regulasi tersebut, daripada menggunakan sumberdaya terbatas untuk aktivitas yang lebih produktif. Regulasi yang berlebihan tidak akan menciptakan tambahan pendapatan daerah dalam jangka panjang.

\section{b. Mempermudah proses perizinan usaha.}

Proses registrasi yang dipersingkat akan mndoong UKM untuk meendaftarkan usahanya menjadi usaha formal. Birokrasi perizinan yang berbelit-belit membuat UKM sulit untuk memiliki surat-surat formal sehingga UKM seringkali menghadapi kesulitan dalam hal memenuhi persyaratan jaminan perbankan. Kecilnya usaha membuat UKM tidak memiliki tanah atau sumber daya penting lainnya untuk melindungi aset keuangan yang dimiliki. 


\section{c. Mempermudah aktivitas subkontrak.}

UKM agar dapat berkompitisi secara efektif dituntut untuk dapat menekan biaya produksinya dengan mengadopsi teknologi usaha yang tepat guna. Aktivitas subkontrak adalah jalan yang paling umum ditempuh untuk menekan sejumlah biaya dan hal ini telah berperan penting dalam kesuksesan integrasi UKM ke dalam usaha yang lebih dinamis.

Di dalam pengembangan peningkatan kemampuan dalam mengembangkan bisnis bukanlah hal yang mudah untuk dilakukan, keinginan tersebut perlu diimbangi dengan kemampuan yang kuat dari pengusaha itu sendiri sebagai kekuatan yang berasal dari dalam atau keterampilan. Pentingnya sekiranya bahwa pengembangan bisnis itu merupakan dari perancanaan bisnis, perencanaan bisnis merupakan penggabungan rencana-rencana fungsional seperti pemasaran, keuangan, manufaktur, dan sumberdaya manusia (Hamali, 2016: hal.118-119).

Zimmer mengemukakan bahwa perencanaan bisnis (business planning) memiliki tiga fungsi pokok, yaitu :

1. Memberikan panduan operasi perusahaan dengan membuat rencana untuk masa yang akan datang dan menyusun strategi untuk mencapai kesuksesannya.

2. Menarik pemberi pinjaman dan investor. Rencana yang dibuat secara sederhana dan hanya ditulis tangan dalam buku catatan tidak cukup untuk mencari pinjaman, karena mengajukan pinjaman atau menarik investor tanpa perencanaan bisnis yang mendalam jarang sekali meraih sukses.

3. Perencanaan bisnis merupakan cerminan dari pembuatnya. Perencanaan bisnis harus menunjukan bahwa wirausahawan telah serius memikirkan perusahaannya dan hal-hal lain yang membuatnya sukses.

Masalah dasar yang dihadapi pengusaha kecil dalam menghadapi pengembangan bisnis, sebagai berikut:

1. Kelemahan dalam memproleh peluang pasar dan memperbesar pangsa pasar. 
2. Kelemahan dalam struktur permodalan dan keterbatasan untuk memproleh jalur terhadap sumber-sumber permodalan.

3. Kelemahan dibidang organisasi dan manajemen sumber daya manusia.

4. Keterbatasan jaringan usaha kerja sama antar pengusaha kecil (sistem informasi pemasaran).

5. Iklim usaha yang kurang kondusif, karena persaingan yang saling mematikan.

6. Pembinaan yang telah dilakukan masih kurang terpadu dan kurangnya kepecayaan serta kepedulian masyarakat terhadap usaha kecil.

\section{Analisis SWOT}

Analisis SWOT adalah penilaian terhadap hasil identifikasi situasi, untuk menentukan apakah suatu kondisi dikategorikan sebagai kekuatan, kelemahan, peluang atau ancaman. Analisis SWOT merupakan bagian dari proses perencanaan. Hal utama yang ditekankan adalah bahwa dalam proses perencanaan tersebut, suatu institusi membutuhkan penilaian mengenai kondisi saat ini dan gambaran ke depan yang mempengaruhi proses pencapaian tujuan institusi. Dengan analisa SWOT akan didapatkan karakteristik dari kekuatan utama, kekuatan tambahan, faktor netral, kelemahan utama dan kelemahan tambahan berdasarkan analisa lingkungan internal dan eksternal yang dilakukan (Alma, dan Priansa, 2009: hal. 115-125).

Analisis SWOT adalah suatu bentuk analisis situasi dengan mengidentifikasi berbagai faktor secara sistematis terhadap kekuatan-kekuatan (strengths) dan kelemahan-kelemahan (weaknesses) suatu organisasi dan kesempatan-kesempatan (opportunities) serta ancaman-ancaman (threats) dari lingkungan untuk merumuskan strategi organisasi.

Strengths (kekuatan) adalah kegiatan-kegiatan organisasi yang berjalan dengan baik atau sumber daya yang dapat dikendalikan. Weaknesses (kelemahan) adalah kegiatan-kegiatan organisasi yang tidak berjalan dengan baik atau sumber daya yang dibutuhkan oleh organisasi tetapi tidak dimiliki oleh organisasi 
Opportunities (peluang / kesempatan) adalah faktor-faktor lingkungan luar yang positif. Threats (ancaman) adalah faktorfaktor lingkungan luar yang negatif.

Matrik SWOT adalah alat untuk menyusun faktorfaktor strategis organisasi yang dapat menggambarkan secara jelas bagaimana peluang dan ancaman eksternal yang dihadapi organisasi dapat disesuaikan dengan kekuatan dan kelemahan yang dimilikinya. IFAS (Internal Strategic Factors Analysis Summary) adalah ringkasan atau rumusan faktor-faktor strategis internal dalam kerangka kekuatan (Strengths) dan kelemahan (Weaknesses).

1. Kekuatan (Strength) adalah situasi internal organisasi yang berupa kompentensi/kapabalitas/sumberdaya yang dimiliki organisasi, yang dapat digunakan sebagai alternatif untuk menangani dan ancaman.

2. Kelemahan (Weakness) adalah situasi internal organisasi dimana kompentensi/kapabalitas/sumberdaya organisasi sulit digunakan untuk menangani kesempatan dan ancaman.

3. Peluang (Opportunity) adalah situasi eksternal organisasi yang berpotensi mengutungkan. Organisasi-organisasi yang berada dalam satu industri yang saama secara umum akan merasa diuntungkan bila dihadapkan pada kondisi eksternal tersebut. Misal, ada segmen pasar tertentu yang belum dimasuki pemain lain, secara umum akan menjadi peluang bagi organisasi manapun yang berhasil melihat pasar tersbut (Tripomo, 2005: hal 118-119).

4. Ancaman (Threat) adalah suatu keadaan eksternal yang berpotensi menimbulkan kesulitan. Organisasi-organisasi yang berada dalam satu industri yang sama secara umum akan merasa dirugikan/ dipersulit/terancam bila dihadapkan pada kondisi eksternal tersebut. Contoh: dua tahun yang akan datang akan masuk "pemain baru" dari luar negri yang memiliki teknologi dan modal kuat. Secara umum kondisi tersebut akan menjadi ancaman bagi semua organisasi yang saat ini berada dalam industri yang sama. 
Metode analisis SWOT bisa dianggap sebagai metode analisis yang paling dasar, yang berguna untuk melihat suatu topik atau permasalahan dari empat sisis yang berbeda. Hasil analisis adalah arahan/rekomendasi untuk mempertahankan kekuatan dan menambah keuntungan dari peluang yang ada, dengan mengurangi kekurangan dan menghindari ancaman. Jika digunakan dengan benar, analisis SWOT akan membantu untuk melihat sisi-sisi yang terlupakan atau tidak terlihat.

Berdasarkan ukuran di atas, ada hal yang perlu diperhatikan dalam pembuatan analisis SWOT, yaitu :

1. Analisis SWOT bisa sangat subjektif, oleh karena itu dua orang menganalisis sebuah perusahaan yang sama, tetapi menghasilkan SWOT yang berbeda.

2. Pembuat analisis harus realistis dalam menjabarkan kekuatan dan kelemahan internal. Kelemahan yang disembunyikan ataukekuatan yang tidak terjabarkan akan membuat arahan strategi menjadi tidak bisa digunakan.

3. Analisis harus didasarkan atas kondisi yang sedang terjadi, bukan situasi yang seharusnya terjadi.

4. Hindari "grey areas". Hindari kerumitan yang tidak perlu dan analisis yang berlebihan.

\begin{tabular}{|c|c|c|}
\hline & $\begin{array}{c}\text { Helpful } \\
\text { To achieve the objectives }\end{array}$ & $\begin{array}{c}\text { Harmful } \\
\text { To achieve the objectives }\end{array}$ \\
\hline 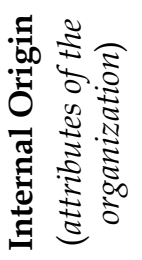 & Strengths & Weakness \\
\hline 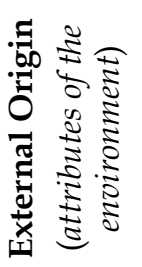 & Opportunities & Threats \\
\hline
\end{tabular}

Gambar 1. Analisis SWOT 


\section{Matriks SWOT}

Matriks SWOT dapat digunakan untuk menggambarkan secara jelas peluang dan ancaman eksternal yang dihadapi perusahaan, dan disesuaikan dengan kekuatan dan kelemahan yang dimilikinya. Matriks SWOT (Kekuatan-Kelemahan-PeluangAncaman) merupakan alat yang penting untuk membantu manajer mengembangkan empat tipe strategi yaitu SO (strengthsopportunities), WO (weakness-opportunities), ST (strengths-threats), dan WT (weaknesess-threats) (Amalia, 2012).

1. Strategi SO adalah strategi yang ditetapkan berdasarkan jalan pikiran organisasi yaitu dengan memanfaatkan seluruh kekuatan untuk merebut dan memanfaatkan peluang sebesar-besarnya. Inilah yang merupakan strategi agresif positif yaitu menyerang penuh inisiatif dan terencana. Strategi yang memanfaatkan kekuatan agar peluang yang ada bisa dimanfaatkan. Data program atau kegiatan yang akan dilaksanakan, kapan waktunya dan dimana dilaksanakan, sehingga tujuan organisasi akan tercapai secara terencana dan terukur. Dalam strategi SO, organisasi mengejar peluang-peluang dari luar dengan mempertimbangkan kekuatan organisasi.

2. Strategi WO adalah strategi yang ditetapkan berdasarkan pemanfaatan peluang yang ada dengan cara meminimalkan kelemahan dalam organisasi. Dalam hal ini perlu dirancang strategi turn around yaitu strategi merubah haluan. Peluang eksternal yang besar penting untuk diraih, namun permasalahan internal atau kelemahan yang ada pada internal organisasi lebih utama untuk dicarikan solusi, sehingga capaian peluang yang besar tadi perlu diturunkan skalanya sedikit. Dalam hal ini kelemahan-kelemahan organisasi perlu diperbaiki dan dicari solusinya untuk memperoleh peluang tersebut.

3. Strategi ST adalah strategi yang ditetapkan berdasarkan kekuatan yang dimiliki organisasi untuk mengatasi ancaman yang terdeteksi. Strategi ini dikenal dengan istilah strategi diversifikasi atau strategi perbedaan. Maksudnya, seberapa besar pun ancaman yang ada, kepanikan dan 
ketergesa-gesaan hanya memperburuk suasana, untuk itu bahwa organisasi yg memiliki kekuatan yang besar yang bersifat independen dan dapat digunakan sebagai senjata untuk mengatasi ancaman tersebut. Dan mengidentifikasi kekuatan dan menggunankannya untuk mengurangi ancaman dari luar.

4. Strategi WT adalah strategi yang diterapkan kedalam bentuk kegiatan yang bersifat defensif dan berusaha meminimalkan kelemahan yang ada serta menghindari ancaman. Karena dalam kondisi ini, organisasi yang sedang dalam bahaya, kelemahan menimpa kondisi internal dangan ancaman dari luar juga akan menyerang. Bila tidak mengambil strategi yang tepat, maka kondisi ini bisa berdampak buruk bagi citra dan eksistensi organisasi kedepan, Yang perlu di lakukan adalah bersama seluruh elemen organisasi merencanakan suatu kegiatan untuk mengurangi kelemahan organisasi, dan menghindar dari ancaman eksternal (Freed, 2010).

\begin{tabular}{|c|c|c|}
\hline & Strengths & Weakness \\
\hline 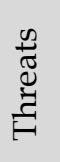 & $\begin{array}{c}\text { ST } \\
\text { Memanfaatkan potensi untuk } \\
\text { menghadapi ancaman }\end{array}$ & $\begin{array}{l}\text { WT } \\
\text { Meminimalkan kelemahan } \\
\text { untuk menghadapi ancaman }\end{array}$ \\
\hline 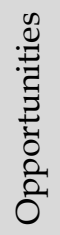 & $\begin{array}{c}\mathrm{SO} \\
\begin{array}{l}\text { Memanfaatkan potensi untuk } \\
\text { meraih peluang }\end{array}\end{array}$ & $\begin{array}{c}\text { WO } \\
\text { Mengatasi kelemahan untuk } \\
\text { meraih peluang }\end{array}$ \\
\hline
\end{tabular}

Gambar 2. Matrik SWOT

\section{Metode Penelitian}

Penelitian ini merupakan penelitian lapangan (field research) dengan pendekatan kualitatif. Lokasi penelitian adalah desa wisata Kaliputu Kabupaten Kudus. Data penelitian diperoleh dengan teknik wawancara langsung dengan sumber informasi yaitu pemilik UMKM usaha jenang dan sebagian masyarakat Desa Kaliputu. 


\section{Hasil Dan Analisis}

Seiring dengan sistem otonomi daerah di mana daerah harus menggali potensi daerah yang dapat dijadikan sebagai modal pembangunan dan dalam rangka meningkatkan daya saing lokal. Jenang Kaliputu Kudus ditetapkan sebagai Produk Unggulan Daerah (PUD). Hal ini dikarenakan jenang kaliputu kudus memiliki nilai ekonomis dan daya saing tinggi serta menyerap tenaga kerja dalam jumlah besar, yang diproduksi berdasarkan pertimbangan kelayakan teknis (bahan baku dan pasar). Talenta atau potensi masyarakat dan kelembagaan pengembangan industri jenang dikembangkan dalam sistem pengembangan ekonomi lokal, dengan membangun kemitraan yang meliputi pemerintah daerah, pengusaha dan organisasi masyarakat lokal.

Pokok-pokok strategi pengembangan bisnis adalah meningkatkan daya tarik, daya tahan, daya saing ekonomi lokal. Setelah mengetahui adanya peluang yang sangat besar selanjutnya menciptakan pengembangan UMKM jenang Kaliputu Kudus, pemerintah daerah berusaha terus menciptakan pertumbuhan ekonomi yang memberikan dampak terhadap masyarakat sekitar dan UMKM, memperluas kesempatan kerja, pemberdayaan produsen dan masyarakat menengah ke bawah.

Usaha kecil yang pada umumnya merupakan unit usaha keluarga, mempunyai jaringan usaha yang sangat terbatas dan kemampuan penestrasi pasar yang rendah. Oleh karena itu produk yang dihasilkan jumlahnya sangat terbatas dan mempunyai kualitas yang cenderung kurang kompetitif. Hal ini berbeda dengan usaha yang sudah besar dan telah mempunyai jaringan yang sudah solid serta didukung dengan teknologi yang dapat menjangkau wilayah yang lebih luas dengan teknik promosi yang baik (Andriyanto dan Nurjanah, 2015).

\section{a. Analisis SWOT UMKM Jenang Desa Wisata Kaliputu Kudus}

Analisis SWOT adalah penilaian terhadap hasil identifikasi situasi, untuk menentukan apakah suatu kondisi dikategorikan sebagai kekuatan, kelemahan, peluang atau ancaman. 
1) Kekuatan (Strength) adalah situasi internal organisasi yang berupa kompentensi/kapabalitas/sumberdaya yang dimiliki organisasi, yang dapat digunakan sebagai alternatif untuk menangani dan ancaman. UMKM desa wisata Kaliputu Kudus mempunyai kekuatan yang sudah teridentifikasi, yaitu:

a) Ketersediaan bahan baku yang melimpah dan mudah didapat

b) Bahan baku seperti tepung ketan, gula merah, kelapa sangat mudah didapatkan di Kudus sehingga juga memudahkan untuk memproduksi jenang.

c) Jenang sudah jadi ikon jajanan khas Kudus

d) Jenang merupakan jajanan khas Kudus yang sudah ada sejak zaman Sunan Kudus dan mendapatkan tempat di hati masyarakat Indonesia pada umumnya.

e) Dukungan pemerintah

f) Pemerintah Daerah melalui Dinas Pariwisata memberi Identitas dengan menjadikan Desa Kaliputu menjadi "Desa Wisata Kalipu Sentra Jenang". Selain itu pemerintah daerah juga menyediakan sarana promosi seperti lewat pameran produk lokal, serta dukungan pemerintah dalam memfasilitasi pengusaha jenang yang tidak memiliki lokasi strategis yang masih kesulitan dalam memasarkan produknya.

2) Kelemahan (Weakness) adalah situasi internal organisasi di mana kompentensi/kapabalitas/sumberdaya organisasi sulit digunakan untuk menangani kesempatan dan ancaman. Berikut identifikasi kelemahan yang ada:

a) Skala usaha yang masih kecil

b) Hal ini disebabkan perusahaan kecil yang ada di desa wisata Kaliputu Kudus yang tidak mempunyai toko di pinggir jalan kesulitan untuk memasarkannya.

c) Kualitas sumberdaya manusia kurang.

3) Peluang (Opportunity) adalah situasi eksternal organisasi yang berpotensi mengutungkan. Organisasi-organisasi yang berada dalam satu industri yang saama secara umum akan merasa diuntungkan bila dihadapkan pada kondisi eksternal tersebut. Identifikasi terhadap peluang yang 
dimiliki UMKM sentra Jenang Desa Wisata Kaliputu Kudus adalah:

a) Permintaan pasar yang tinggi.

b) Daya jual beli masyarakat yang semakin meningkat.

c) Banyak event acara tradisional sebagai sarana promosi UMKM

d) Adanya event tradisi tahunan ini bisa menjadi daya tarik bagi para wisatawan baik domestik maupun mancanegara. Sehingga warga Desa Kaliputu sebagai penghasil jenang bisa merasakan manfaat dengan datangnya wisatawan yang berkunjung. Salah satu upacara tradisional adalah "Tebokan Jenang" yang sudah menjadi agenda rutin pemerintah Kota Kudus. Selain sebagai bentuk rasa syukur kepada Tuhan, event ini diagendakan sebagai wisata budaya sekaligus sarana promosi bagi pengusaha jenang untuk berkretivitas agar lebih dikenal di masyarakat luas.

4) Ancaman (Threat) adalah suatu keadaan eksternal yang berpotensi menimbulkan kesulitan. Organisasi-organisasi yang berada dalam satu industri yang sama secara umum akan merasa dirugikan/dipersulit/terancam bila dihadapkan pada kondisi eksternal tersebut. Identifikasi terhadap ancaman yang ada di UMKM Sentra Jenang Desa Kaliputu:

a) Persaingan banyak; Biasanya persaingan muncul itu lebih pada produk jenang dari luar kaliputu dan tergeser oleh makanan-makanan yang lebih modern seperti zaman sekarang.

b) Munculnya produk substitusi dari industri modern.

c) Rendahnya minat masyarakat dalam mengembangkan usaha. Sebagian besar usaha jenang merupakan usaha keluarga yang diwariskan turun temurun dari generasi sebelumnya. Seiring dengan perkembangan jaman, dikhawatirkan muncul keengganan generasi selanjutnya untuk melanjutkan usaha keluarga.

d) Sebagian masyarakat lebih memilih menjadi buruh pabrik dibandingkan harus mulai usaha dengan merintisnya dari nol. 


\section{b. Matriks SWOT}

Setelah mengetahui strength (Kekuatan), weakness (ancaman), opportunity (peluang), threat (ancaman) yang ada pada UMKM desa wisata Kaliputu Kudus, Maka langkah selanjutnya adalah menyusun matriks SWOT. Matriks SWOT adalah alat yang penting untuk membantu manajer mengembangkan empat tipe strategi yaitu SO (strengths-opportunities), WO (weakness-opportunities), ST (strengths-threats), dan WT (weaknesess-threats).

1) Strategi $\mathrm{SO}$ adalah strategi yang ditetapkan berdasarkan jalan pikiran organisasi yaitu dengan memanfaatkan seluruh kekuatan untuk merebut dan memanfaatkan peluang sebesarbesarnya. Inilah yang merupakan strategi agresif positif yaitu menyerang penuh inisiatif dan terencana. Data program atau kegiatan yang akan dilaksanakan, kapan waktunya dan dimana dilaksanakan, sehingga tujuan organisasi akan tercapai secara terencana dan terukur. Dalam strategi SO, organisasi mengejar peluang-peluang dari luar dengan mempertimbangkan kekuatan organisasi. Strategi yang disusun berdasarkan analisis ini adalah:

- Meningkatkan mutu produk

Mutu produk yang ada hendaknya terus menerus untuk selalu ditingkatkan. Hal ini mengingat sifat jenang yang memiliki masa konsumsi yang relative tidak lama. Dengan tetap menjaga nilai kesehatan, perlu terus diusahakan agar produk jenang memiliki daya tahan yang cukup lama sehingga akan mampu dipasarkan ke luar daerah Kudus.

- Meningkatkan promosi

Dukungan pemerintah juga memegang peranan penting dalam mengembangkan usaha jenang pada UMKM Sentra Jenang desa wisata Kaliputu Kudus.

2) Strategi WO adalah strategi yang ditetapkan berdasarkan pemanfaatan peluang yang ada dengan cara meminimalkan kelemahan dalam organisasi. Dalam hal ini perlu dirancang strategi turn around yaitu strategi merubah haluan. Peluang eksternal yang besar penting untuk diraih, namun 
permasalahan internal atau kelemahan yang ada pada internal organisasi lebih utama untuk dicarikan solusi, sehingga capaian peluang yang besar tadi perlu diturunkan skalanya sedikit. Dalam hal ini kelemahan-kelemahan organisasi perlu diperbaiki dan dicari solusinya untuk memperoleh peluang tersebut. Identifikasi strategi dari hasil analisis ini adalah:

- Meningkatkan skala usaha

Dorongan untuk mengembangkan usaha hendaknya terus menerus ditingkatkan. Hal ini tetap memerlukan dukungan pemerintah khususnya pemerintah daerah agar skala industri jenang dapat dikembangkan untuk menangkap peluang pasar yang masih terbuka.

- Perlu dilakukan usaha-usaha untuk mengembangkan kualitas SDM. Hal ini dapat dilakukan dengan mengikutkan karyawan pada pelatihan-pelatihan peningkatan kompetensi karyawan usaha jenang. Pemerintah juga dapat mengambil bagian untuk andil dalam meningkatkan kualitas SDM usaha jenang ini.

3) Strategi ST adalah strategi yang ditetapkan berdasarkan kekuatan yang dimiliki organisasi untuk mengatasi ancaman yang terdeteksi. Strategi ini dikenal dengan istilah strategi diversifikasi atau strategi perbedaan. Maksudnya, seberapa besar pun ancaman yang ada, kepanikan dan ketergesa-gesaan hanya memperburuk suasana, untuk itu bahwa organisasi yg memiliki kekuatan yang besar yang bersifat independen dan dapat digunakan sebagai senjata untuk mengatasi ancaman tersebut diharapkan mampu mengidentifikasi kekuatan dan menggunankannya untuk mengurangi ancaman dari luar. Identifikasi strategi dari hasil analisis ini adalah:

- Meningkatkan minat wirausaha jenang

Peran ini dapat diambil oleh pemerintah misalnya dengan memberikan dorongan berwirausaha jenang. Peningkatan minat berwirausaha juga dapat dilakukan oleh berbagai pihak terkait lainnya seperti akademisi dan Lembaga swadaya masyarakat. 
- Meningkatkan kreatifitas dalam beriklan. Penggunaan internat sebagai media promosi terus ditingkatkan agar jenang Kudus dapat tersebar ke seluruh penjuru dunia.

- Pemerintah terus berusaha meningkatkan kesadaran dan kecintaan masyarakat Kudus khususnya akan produk Jenang. Jenang sudah menjadi ikon Kota Kudus dalam hal jajanan. Hal yang dapat dilakukan misalnya ketersediaan jenang pada acara-acara rutin, seperti rapat dan pertemuan lainnya.

4) Strategi WT adalah strategi yang diterapkan ke dalam bentuk kegiatan yang bersifat defensif dan berusaha meminimalkan kelemahan yang ada serta menghindari ancaman. Karena dalam kondisi ini, organisasi yang sedang dalam bahaya, kelemahan menimpa kondisi internal dangan ancaman dari luar juga akan menyerang. Bila tidak mengambil strategi yang tepat, maka kondisi ini bisa berdampak buruk bagi citra dan eksistensi organisasi ke depan. Hal yang perlu di lakukan adalah bersama seluruh elemen organisasi merencanakan suatu kegiatan untuk mengurangi kelemahan organisasi, dan menghindar dari ancaman eksternal. Identifikasi strategi pada analisis ini adalah:

- Meningkatkan kerjasama antar pengusaha jenang, misalnya melakukan promosi bersama, menyelenggarakan kegiatan peningkatkan kompetensi karyawan, dan juga pembinaan terhadap usaha jenang yang masih dalam tahap rintisan dan masih belum berkembang.

- Munculnya produk substitusi dapat diantisipasi dengan meningkatkan inovasi produk jenang, misalnya dalam hal cita rasa, kemasan, penyajian dan lain sebagainya.

\section{Simpulan}

Berdasarkan pembahasan penelitian yang telah dilakukan, maka hasil penelitian ini menunjukkan:

1. UMKM Sentra Jenang desa wisata Kaliputu Kudus diharapkan untuk terus berinovasi dalam meningkatkan kualitas produknya 
2. Usaha pemasaran yang sudah dilakukan hendaklah perlu untuk terus dikembangkan dengan menggunakan media informasi yang sesuai dengan perkembangan jaman.

3. Dukungan pemerintah diharapkan terus meningkat untuk membantu meningkatkan kualitas SDM dan promosi UMKM Sentra Jenang desa wisata Kaliputu Kudus

4. Diperlukan dukungan dan komitmen yang kuat dari berbagai pihak terkait dalam menjadikan Desa Kaliputu sebagai sentra jenang di Kabupaten Kudus. 


\section{DAFTAR PUSTAKA}

Alma, Buchari dan Priansa, Donni Juni. 2009. Manajemen Bisnis Syariah, Alfabeta: Bandung. hal. 115-125)

Amalia. Alif, Wahyu Hidayat, Agung Budiatmo. 2012. Analisis Strategi Pengembangan Usaha Pada UKM Batik. Jurnal Admistrasi Bisnis vol. 1 No. 1

Andriyanto, Irsad dan Nurjanah. 2015. Strategi Klaster Industri Menghadapi Pasar Global. Jurnal Bisnis dan Manajemen Islam. Vol. 03 Nomor 01. Juni. hal. 85-114.

Anoraga, Pandji. 2011. Pengantar Bisnis. PT. Rieneka Cipta: Jakarta. hlm. 5-7.

Dafid, F.R. 2010. Manajemen Strategis Konsep. Salemba Empat. Jakarta hal. 327-330.

Hamali, Arif Yusuf. 2016. Pemahaman Strategi Bisnis \& Kewirausahaan. Prenada. Media Group: Jakarta. hlm. 112.

Pramiyanti, Alila. 2008. Studi Kelayakan Bisnis untuk UKM. Media Pressindo. Yogyakarta.

Pramudiana, Yudi. dan Riris Rismayani. 2016. Business Plan. PT. Remaja Rosdakarya: Bandun. hlm. 11-12.

Tripomo, Tejo. 2005. Manajemen Strategi. Rekayasa Sains: Bandung. hal. 118-119. 